\title{
O NORDESTE E A QUESTÃO AGRÁRIA: discursos de um periódico católico para o campo cearense, 1961-63
}

\author{
Max Fellipe Cezario Porphirio*
}

\begin{abstract}
RESUMO: Nosso trabalho consiste em analisar a utilização d'O Nordeste - jornal católico cearense - como instrumento de propagação das diretrizes da hierarquia católica para o campo brasileiro. As mudanças pelas quais esse jornal passou entre 1961 e 1963, no que se refere ao trato da questão agrária, são elucidativas sobre o esforço despendido pela hierarquia católica na luta pela organização política do trabalhador rural. Adotando como referências teórico-metodológicas as ideias desenvolvidas por Jean-Noël Jeanneney, Norman Fairclough, Regina de Luca, Cruz e Peixoto, procuramos fazer uma análise bidimensional do discurso desse periódico, discutindo tanto sua estrutura textual - vocabulário e estratégias argumentativas - como a conjuntura políticoeconômica na qual se inseria. Para tanto, dividimos o artigo em três partes: apresentaremos as formas de atuação da Igreja Católica no campo brasileiro; discutiremos a maneira pela qual $O$ Nordeste noticiou os problemas rurais entre 1961 e 1963; debateremos como os trabalhadores rurais foram caracterizados por esse periódico.

PALAVRAS-CHAVE: Imprensa; Trabalhadores rurais; Igreja; Questão agrária.
\end{abstract}

\section{$O$ nordeste and the agrarian issue: speeches from a catholic journal to the cearense countryside, 1961-63}

ABSTRACT: This article consists in analyzing the use of the O Nordeste - Catholic newspaper of Ceara - as a tool for spreading the guidelines of the Catholic hierarchy for the Brazilian countryside. The changes that this newspaper went through between 1961 and 1963, in relation to the treatment of the agrarian issue, are illustrative of the effort expended by the Catholic hierarchy in the struggle for the political organization of the rural worker. Adopting as theoretical-methodological references the ideas developed by Jean-Noël Jeanneney, Norman Fairclough, Regina de Luca, Cruz and Peixoto, we attempt to make a two-dimensional analysis of this journal's speech, discussing both its textual structure - vocabulary and argumentative strategies - and the politicaleconomic context in which it was placed. For this purpose, we divide the article into three parts: we will present the performance forms of the Catholic Church in the Brazilian countryside; we will discuss the way by which $\mathrm{O}$ Nordeste reported the rural problems between 1961 and 1963; we will discuss how the rural workers were characterized by this newspaper.

KEYWORDS: Press; Rural Workers; Church; Agrarian question.

\section{$O$ nordeste y la cuestión agraria: discursos de un periódico católico para el campo cearense, 1961-63}

RESUMEN: Nuestro artículo consiste en analizar la utilización del $O$ Nordeste - diario católico del Ceará como instrumento de propagación de las directrices de la jerarquía católica para el campo brasileño. Los cambios por los que ese periódico pasó entre 1961 y 1963, en lo que se refiere al sentido de la cuestión agraria, son esclarecedores sobre el esfuerzo de la jerarquía católica en la lucha por la organización política del trabajador rural. Adoptando como referencias teórico-metodológicas las ideas desarrolladas por Jean-Noël Jeanneney, Norman Fairclough, Regina de Luca, Cruz y Peixoto, buscamos hacer un análisis bidimensional del discurso de ese periódico, discutiendo tanto su estructura textual - vocabulario y estrategias argumentativas - como la coyuntura político-económica en que estaba inserto. Para ello, dividimos el artículo en tres partes: presentaremos las formas de actuación de la Iglesia Católica en el campo brasileño; discutiremos como $O$ Nordeste notició los problemas rurales entre 1961 y 1963; debatiremos como los trabajadores rurales fueron caracterizados por ese periódico.

PALABRAS CLAVE: Prensa; Trabajadores rurales; Iglesia; Cuestión agraria.

\footnotetext{
*Mestre em História pela Universidade Federal Rural do Rio de Janeiro. Atualmente é Doutorando no Programa de Pós-Graduação da mesma Universidade. Contato: Rodovia BR 465, Km 07, s/n, Zona Rural, CEP: 23890-000 Seropédica-RJ, Brasil. E-mail: max_fcp@ hotmail.com. ORCID: https://orcid.org/0000-0002-1498-7542.
} 


\section{O discurso da Igreja}

Em 1945 vemos cair o Estado Novo Varguista, a experiência autoritária que vigorou sete anos, e ascender a democracia. Essa ascensão criou as condições necessárias para a realização de ricos e amplos debates políticos, ideológicos e culturais, e para que as lutas, particulares e pontuais, pela permanência na terra ganhassem maior visibilidade. A Igreja Católica participou ativamente desses debates, lançando proposições sobre e para o campo brasileiro, que, entre 1945 e 64 - período que aqui nos interessa -, podem ser divididas em três fases: a) de 1945 a 50 - momento em que a Igreja tratou os problemas rurais de forma difusa e sem grande interesse por parte da hierarquia eclesiástica; b) de 1950 a 61 - período que marcou a transição para um argumento unívoco e articulado com as instâncias superiores da instituição; c) de 1961 a 64 - fase caracterizada pela atuação sistemática da Igreja Católica no campo por meio do Movimento de Educação de Base (MEB), da Ação Católica e da fundação de sindicatos ${ }^{1}$.

Entre 1945 e 1950, a Igreja - baseada na ideia de que a sociedade brasileira era constituída por esferas autônomas - apresentava-se como uma instituição acima das querelas políticas e econômicas do seu tempo, preocupada somente com a questão social, em especial com a preservação dos valores considerados imprescindíveis para o desenvolvimento harmonizador da nação: a justiça social e a caridade. Dessa forma, o episcopado - em concordância com os argumentos que tramitavam no Congresso Nacional na década de 1940 - defendia que a resolução dos problemas agrícolas estaria na melhora da qualidade de vida da população rural mediante o direito à propriedade privada, na difusão do cooperativismo e do crédito agrícola, na extensão da legislação trabalhista ao campo, na superação da relação desigual entre a indústria e a agricultura, na fixação dos trabalhadores rurais, na promoção da assistência social, na mecanização e na implantação do ensino agrícola. O episcopado também discutia as bases para a ação da Igreja no campo, prevendo a propagação da sua doutrina a partir da imprensa, da educação de jovens e adultos, da alfabetização, da formação social de estudantes e da atuação dos círculos operários católicos. Porém, os elementos considerados essenciais para a superação dos problemas rurais seriam a articulação com os grandes proprietários de terra e o Estado, responsáveis, respectivamente, por praticar a caridade e a justiça social; e o estímulo à conciliação de classes, evitando assim a transformação do "harmonioso" meio rural em um espaço de contestação e desagregação, como era o meio urbano $^{2}$ - argumento semelhante ao de parte do Ministério da Agricultura e dos grandes proprietários, que, para ratificar a sua posição contrária à sindicalização classista, sinalizava a 
"harmonia" entre empregados e empregadores no campo, remetendo os conflitos de classe à cidade $^{3}$.

A década de 1950 significou a transição de um discurso difuso e à parte da hierarquia da Igreja para um unívoco e articulado com as instâncias superiores da instituição ${ }^{4}$. Para entender essa mudança é preciso abordar dois aspectos da conjuntura político-econômica brasileira dessa década. Nesse momento, dois grandes grupos teorizaram sobre os rumos da economia: os nacional-desenvolvimentistas, grupamento de origem liberal e composto principalmente por intelectuais aglutinados no Instituto Superior de Estudos Brasileiros (ISEB); e os nacionalistas econômicos, ligados aos setores mais à esquerda da política brasileira, como o Partido Comunista Brasileiro (PCB). Como poderíamos esperar em um país essencialmente rural, a questão agrária assumiu importante dimensão nas proposições de ambos. Apesar de divergirem quanto ao papel político e social do capitalismo, ambos associavam a ideia de "desenvolvimento nacional" à elevada produtividade industrial por habitante ${ }^{5}$, considerando a superação do sistema agroexportador condição primordial para a formação de uma economia centrada no mercado interno, uma vez que a sobreposição desse modelo aumentaria tanto o fornecimento de alimentos para as cidades e de matérias-primas para a indústria como o poder aquisitivo da população rural ${ }^{6}$.

A década de 1950 também teve como característica a presença do capital monopolista na agricultura. Tal presença, ao transformar os posseiros em trabalhadores diaristas, aumentou a exploração e, consequentemente, a miséria da população rural $^{7}$. Enquanto parte dessa população respondeu a essas mudanças migrando para áreas urbanas - lá também seria explorada, porém, a qualidade de vida era melhor $^{8}-$, outra parte se organizou em torno de associações e movimentos armados ${ }^{9}$. Nesse contexto a Igreja lançou a carta pastoral Conosco, sem nós ou contra nós se fará a reforma rural (1950). Essa carta, como o próprio título sugere, demonstrou a preocupação episcopal em manter sua influência e legitimidade frente a setores não-patronais, cada vez mais próximos do PCB - que desde 1946 atuava sistematicamente no campo brasileiro, organizando categorias rurais não assalariadas e assalariadas. Em concordância com as ideias propostas pelo Ponto IV, o episcopado interpretou a pobreza como a porta de entrada para a influência de ideologias de esquerda ${ }^{10}$. Portanto, para evitar a expansão do comunismo, propôs melhoras nas condições de vida da população rural, mediante a humanização do trabalho, o incentivo ao ensino técnico agrícola, a promoção da assistência médica, a instauração de políticas previdenciárias e a facilitação do acesso à terra para cultivo ${ }^{11}$. 
No ano seguinte, o episcopado brasileiro apresentou a Pastoral Coletiva (1951), que possuía um capítulo reservado à discussão da reforma agrária. Pela primeira vez, a Igreja propôs alterações na estrutura fundiária, defendendo uma reforma, baseada na propriedade privada, a ser introduzida com parcimônia, de forma a evitar que tais mudanças resultassem em desestabilização da ordem. Além disso, esse projeto previa o estímulo à educação técnica e repartição de terras abandonadas, a extensão da legislação trabalhista aos trabalhadores rurais, o incentivo a formação de cooperativas, a fixação do trabalhador rural no campo e a reforma do sistema de taxação da terra. Como destacou Carvalho, essas proposições tinham como principais objetivos: tornar inviável o uso coletivo da terra; frear a extensão da proletarização no campo; promover o desenvolvimento de uma classe média rural, ancorada na propriedade privada da terra - considerada importante elemento na contenção do avanço comunista $^{12}$.

Em 1952, a Igreja lançou mais uma declaração sobre o campo brasileiro, A Igreja e o Vale do São Francisco. Esse documento objetivava influenciar as políticas da Comissão Nacional de Política Agrária (CNPA) ${ }^{13}$. Alarmado pelas propostas da CNPA de contornar, por meio de emenda constitucional, o parágrafo 16 do artigo $141^{14}$ e desapropriar terras incultas, mal-cultivadas e/ou adquiridas para fins especulativos, o episcopado posicionou-se contra a desapropriação sistemática das propriedades, por acreditar não existir recursos, "clima psicológico nem maturidade política para tanto" ${ }^{15}$. Propôs que a saída seria uma reforma agrária assistida pelos proprietários, que seriam estimulados a concederem as partes subaproveitadas em troca de recursos técnicos ou de crédito ${ }^{16}$.

Apesar de esses documentos indicarem a forma pela qual o episcopado brasileiro pensava o campo na década de 1950, foram os dois Encontros dos Bispos do Nordeste, realizados em 1954 e 1959, que demarcaram o lugar da Igreja no debate sobre reforma agrária brasileira $^{17}$. Nesses encontros, a Igreja reafirmou a necessidade de superar os problemas do campo para alcançar o desenvolvimento nacional. Para tanto, propôs a criação de condições para a fixação do trabalhador no campo a partir da aquisição de propriedades privadas, da concessão de créditos - que deveriam ser revertidos na modernização da produção - e do estímulo ao ensino técnico agrícola ${ }^{18}$. Além disso, bispos de Alagoas, que participaram do encontro de 1959, decidiram pela criação do Sistema Rádio-educativo de Sergipe (SIRESE), um programa de educação de base, pautado na utilização de escolas radiofônicas ${ }^{19}$.

É lugar comum na historiografia apontar que, na década de 1960, a Igreja Católica passou por um processo de reorganização, tanto no âmbito nacional quanto internacional. Para análise desse processo é necessário considerar o contexto da guerra fria, já que o crescimento 
do marxismo "ateu" sobre a América Latina foi a força motriz por trás da encíclica Mater et Magistra (1961) e das conclamações de 1958 e 1961, marcos da reorganização católica ${ }^{20}$. Nessa conjuntura, o argumento do episcopado brasileiro sobre a necessidade da própria Igreja guiar a reforma agrária como forma de evitar a expansão do comunismo ficou explícito, além disso, a forma pela qual a Igreja pensou a constituição da reforma agrária mudou. Em concordância com as proposições da encíclica (1961) - especificadamente, a ideia de que a promoção dos agricultores deveria ser realizada pelos próprios agricultores -, o episcopado deixou de apoiar a atuação primordial dos grandes proprietários na implantação da reforma, para estimular a ação reivindicatória dos trabalhadores rurais. A espinha dorsal desse estímulo foi o Movimento de Educação de Base (MEB) ${ }^{21}$.

Ainda que represente a estruturação nacional de práticas já iniciadas pela Igreja com o Sistema Rádio-educativo de Sergipe (SIRESE) e o Serviço de Assistência Rural (SAR), o MEB mudou a forma de tratar a educação no campo ${ }^{22}$. Entre 1910 e 1961, os projetos de educação da população rural, ao negligenciarem os conflitos de classe e concentrarem-se na capacitação técnica, reafirmavam a explicação da improdutividade rural a partir da incapacidade técnica dos trabalhadores rurais, como defendiam as entidades patronais ${ }^{23}$. A própria Igreja Católica havia compactuado com esse discurso e essa forma de oferecer educação à população rural, quando lançou, na década de 1950, a Campanha Nacional de Educação Rural ${ }^{24}$. O MEB, por ter sido gerado em um momento de mudança interpretativa da Igreja, partiu do pressuposto que a educação seria capaz de "conscientizar" o trabalhador rural dos conflitos de classe em que estava inserido ${ }^{25}$. Três fatores justificaram a ênfase nesse projeto de educação por meio de escolas radiofônicas no Norte, Nordeste e Centro-Oeste: 1) a ideia de que a população rural deveria estar "consciente" das formas de dominação as quais estava submetida, para então se organizar politicamente; 2) os católicos progressistas acreditavam que a referida "conscientização" ocorreria por meio da promoção de uma "nova" e "endógena" cultura popular- em oposição àquela imposta e alienante -, a ser estimulada pela alfabetização; 3) nas teorizações da Igreja Católica brasileira, o foco na juventude rural era enfatizado, pois dela surgiriam as futuras lideranças rurais, que atuariam na organização da população rural $^{26}$.

O MEB fundou escolas, cooperativas agrícolas e sindicatos em quinhentos municípios de quinze estados: Alagoas, Amazonas, Bahia, Ceará, Goiás, Maranhão, Mato Grosso, Minas Gerais, Pará, Paraíba, Pernambuco, Piauí, Rio Grande do Norte, Rondônia e Sergipe ${ }^{27}$. O movimento consolidou-se no ano de 1963, quando possuía 7.353 escolas radiofônicas e alfabetizou 120.000 trabalhadores rurais - cerca de $40 \%$ do total de alunos alfabetizados pelo 
movimento durante os seis primeiros anos de atuação ${ }^{28}$. Em setembro de 1963, com a mudança de horário do programa Voz do Brasil, o movimento alterou o horário das aulas ${ }^{29}$. Tal alteração contribuiu para que o número de escolas diminuísse, todavia essa não foi a única razão. Apesar da ditadura civil-militar, instaurada em 1964, não ter perseguido diretamente o MEB, os membros do movimento, preocupados com o terror que assolava o campo brasileiro, praticaram a autocensura e saíram da organização. Além disso, a hierarquia católica, em 1965, passou a intervir diretamente na organização do MEB e a exigir a execução de atividades que não condiziam com os objetivos iniciais do movimento, como a catequese - talvez tenha sido essa uma tentativa de garantir a não subversão e, também, a não perseguição dos seus quadros. O movimento não resistiu a essas mudanças organizacionais e políticas, encerrando suas atividades, em diversas regiões, no ano de $1966^{30}$.

Outras formas de organização política da população rural foram empreendidas pela Igreja, durante as décadas de 1950 e 1960. Vejamos os casos, mais abordados pela historiografia, dos estados do Rio Grande do Sul, São Paulo, Pernambuco e Rio de Janeiro. Em 1960 foi criado o Movimento de Agricultores Sem Terra (MASTER), cujo objetivo era evitar a desapropriação de 300 famílias de uma área de 1.800 hectares no município de Encruzilhada do Sul (RS). Até o final de 1961 a organização era incipiente. Em 1962, esse quadro mudou e o MASTER teve considerável impulso, justificado pela relação intrínseca com o governador Leonel Brizola, que participava da organização dos acampamentos e enviava, quando possível, a Brigada Militar a fim de evitar o emprego de violência por parte dos proprietários contra aqueles que o MASTER aglutinou sobre a bandeira da desapropriação: assalariados rurais, pequenos proprietários, posseiros, parceiros, agregados e arrendatários $^{31}$. O MASTER não era o único movimento social que atuava nos campos riograndenses. A preocupação com a sindicalização rural motivou, em 1961, a formação católica de Frentes Agrárias, cujo objetivo principal era conter a expansão do comunismo nas áreas rurais. Diversos municípios do Rio Grande do Sul tiveram a sua Frente Agrária ${ }^{32}$.

Com relação a São Paulo, tomemos como exemplo a Alta Mogiana, uma das zonas cafeeiras mais antigas do estado. Na segunda metade da década de 1940, essa região, assim como outras regiões do interior do estado de São Paulo, caracterizou-se pela presença significativa de comitês rurais do PCB. A região era palco da disputa entre o PCB e a Igreja Católica pela representação do trabalhador rural, sendo esta representada pelo padre Celso Ibson de Syllos. A partir de 1962, o padre Syllos contribuiu para a fundação de diversos sindicatos rurais na região. Padre Celso também era editor do jornal Diário de Notícias, 
veículo da arquidiocese de Ribeirão Preto, que ele transformou, a partir de 1961, em veículo de comunicação com o objetivo de organizar politicamente o público rural $^{33}$.

Também em 1961, respondendo à expansão das Ligas Camponesas, iniciou-se a sistematização e organização dos sindicatos católicos em Pernambuco, por meio do Serviço de Orientação Rural de Pernambuco (SORPE), ligado aos círculos operários e ao Ministério do Trabalho. O SORPE tinha a função de formar líderes sindicais católicos. Apesar de os sindicatos ligados à Igreja se preocuparem majoritariamente com o cumprimento das leis trabalhistas, a defesa da reforma agrária cristã - que, na década de 1960, consistia na defesa de reformas sociais para o campo, como o acesso da população rural a previdência social, assistência médica, educação e saúde pública - também fazia parte da sua agenda ${ }^{34}$.

Na década de 1950, existiam, no Rio de Janeiro, duas federações que disputavam a representação dos trabalhadores rurais: a Federação das Associações de Lavradores do Estado do Rio de Janeiro (FALERJ), ligada ao PCB, e a Federação dos Lavradores do Estado do Rio de Janeiro (FLERJ), ligada ao governo estadual. Baseada na ideia de que a alteração na estrutura agrária ocorreria por meio da aliança entre o Estado e a Igreja, a Federação dos Círculos Operários passou a atuar no campo fluminense, se aliando à FLERJ com o objetivo de se apoiar nessa organização para expandir sua atuação frente aos trabalhadores rurais, fundando associações de lavradores e $\operatorname{sindicatos}^{35}$. Como veremos no próximo tópico, ao exemplo das estratégias praticadas em Pernambuco e Rio de Janeiro, a Igreja utilizou os círculos operários como instrumento de ação no campo cearense.

\section{A ação da Igreja Católica no campo cearense}

Na década de 1960, o estado do Ceará, assim como a maioria dos estados brasileiros, era majoritariamente rural, com $67 \%$ da população economicamente ativa associada à produção agrícola. Essa população vivia em um Ceará marcado pela concentração fundiária, onde $12 \%$ da área total era composta por pequenas propriedades, $57 \%$ por médias propriedades e $31 \%$ por latifúndios ${ }^{36}$. Analisando a área destinada à lavoura, esses números são ainda mais estarrecedores. Em 1963, 90\% das terras pertenciam a 3\% dos proprietários ${ }^{37}$. Tal quadro socioeconômico, somado às sucessivas secas, estimulou a migração rural dos cearenses, que, nesse período, chegaram a compor $11,3 \%$ do total de migrantes nordestinos. Esses migrantes, que partiam principalmente de Uruburetama, Fortaleza, Litoral de Pacajús, Serra de Baturité, Serra do Pereiro, Sertão do Salgado e Cariri, tinham destinos variados: 
$34,6 \%$ partiam para o Norte, $8,6 \%$ para o Sudeste, 14,6\% para o Centro-oeste, $14,9 \%$ para o sul e 27,3\% para os demais estados do próprio Nordeste ${ }^{38}$.

Além de favorecer o êxodo rural, a concentração fundiária abriu caminho para a atuação do PCB, que, em 1955, lançou as bases para a criação da União dos Lavradores e Trabalhadores Agrícolas do Ceará (ULTAC), filiada à recém criada União dos Lavradores e Trabalhadores Agrícolas do Brasil (ULTAB). A ULTAC representou a solidificação dos esforços empreendidos pelos comunistas desde 1945, quando ocorreu a delineação da ação do PCB para o campo cearense. Em concordância com as estratégias comunistas para a promoção da sindicalização rural, em 1957 a ULTAC foi substituída pela Federação dos Lavradores e Trabalhadores Agrícolas do Ceará (FALTAC) ${ }^{39}$. A FALTAC, apesar de contar com a presença de padres nas suas mobilizações, disputava com a Igreja a representatividade dos trabalhadores rurais ${ }^{40}$.

A Igreja atuava por meio dos círculos operários, presentes em quase todos os municípios do interior cuja atividade principal era a agrícola - por exemplo, em 1953, dos 88 círculos operários, 70 estavam localizados no interior ${ }^{41}$. Os círculos operários tiveram importante papel na organização dos trabalhadores rurais em torno dos sindicatos católicos durante os três primeiros anos da década de 1960. Para instrumentalizar essa organização, os circulistas cearenses utilizaram duas ferramentas: o Serviço Social Rural (SSR) e a Escola de Líderes Rurais (ELIRUR). O SSR foi criado no ano de 1958, mesmo ano em que, por decorrência de uma grande seca, a legitimação dos círculos operários frente aos trabalhadores rurais perdeu força, resultando no fechamento de alguns núcleos, na redução do número de filiados e no aumento do número de inadimplentes. O SSR, além de oferecer educação técnica e profissional, tinha como principal objetivo vigiar ideologicamente os trabalhadores rurais ${ }^{42}$. A Escola de Líderes Rurais (ELIRUR), por sua vez, ministrava cursos de noções de economia política, legislação agrária, sindicalismo e cooperativismo como forma de transmitir os valores doutrinários da hierarquia católica ${ }^{43}$.

Para alcançar os círculos interioranos, a Federação dos Círculos Operários do Ceará lançou, em setembro de 1950, o periódico A Fortaleza. Esse periódico semanal era utilizado para publicar editais de convocações às assembleias circulistas, apresentar notícias eclesiásticas, criticar a carestia dos gêneros alimentícios, destacar a precária realidade socioeconômica do trabalhador rural, criticar a ausência de incentivo governamental à produção agropecuária, enaltecer a ação norte-americana de combate ao comunismo e associar o comunismo à escravização do trabalhador rural. Esses tópicos também estavam presentes nas proposições do $O$ Nordeste, porém, ao contrário do A Fortaleza, esse periódico 
tentou estabelecer relação mais próxima com os trabalhadores rurais após a hierarquia católica sistematizar suas ações no campo brasileiro em $1961^{44}$.

\section{Da questão técnica à questão política}

O Nordeste era um periódico da "grande imprensa" cearense, ligado ao Arcebispado Metropolitano de Fortaleza, que circulou entre 1922 e 1967. Em 1961 era um periódico diário de 8 páginas, escrito em uma linguagem simples e direta, composto por imagens (fotos e tirinhas) e que tinha o seguinte expediente: diretor, Com. Luís Sucupira; redator secretário, Dr. Paulo Lopes Filho; gerente, Ignez Tocantins ${ }^{45}$. O Nordeste se apresentava como um jornal “ideológico" e "doutrinal" 46 . Dessa forma, não é preciso mencionar que o periódico veiculava as doutrinas da Igreja Católica, apresentava colunas assinadas por padres e bispos, noticiava o aniversário e viagens de altos membros do clero, divulgava notícias da arquidiocese de Fortaleza, sede administrativa do jornal, e anunciava as graças alcançadas pelos leitores.

O que nos permite classificar $O$ Nordeste como um periódico lido por trabalhadores rurais? O fato legitimador dessa relação emissor/reprodutor são as cartas que lavradores e pequenos proprietários enviavam à redação. Por exemplo, na primeira página da edição de 3 de fevereiro de 1961, vemos a notícia "Sementes para agricultores" com o seguinte conteúdo: “Temos recebido numerosas cartas de agricultores, pedindo que 'O Nordeste' interfira junto à Secretaria de Agricultura, no sentido de que inicie, urgentemente, a distribuição de semente e enxadas". Ademais, o jornal contava com colunas fixas relacionadas ao interior cearense, publicava editais de convocação às assembleias dos sindicatos rurais dirigidos pela Federação dos Círculos Operários do Ceará, fornecia orientação agropecuária na coluna "Nordeste Agrícola" e instruía sobre a política de crédito agrícola. A forma como, possivelmente, os trabalhadores rurais - em sua maioria analfabetos - tinham acesso às notícias desse jornal era por meio da leitura coletiva, como sugere o relato do Padre Misael Alves de Souza, de Limoeiro do Norte, em carta enviada à redação: “O Nordeste! Não queira saber da repercussão que alcançou aqui: passara de mão em mão. Foi lido em altas vozes na cidade!"47 . Porém, isso não significa dizer que o periódico era voltado exclusivamente ao trabalhador rural. Em concordância com as proposições da Igreja, que pregava a harmonia e a cooperação entre as classes, o periódico era voltado a diferentes grupos sociais, como industriais ${ }^{48}$, estudantes ${ }^{49}$ e profissionais liberais ${ }^{50}$.

Em razão da sua importância na história da imprensa cearense, diferentes pesquisadores utilizaram o $O$ Nordeste como fonte, porém encontramos, até o momento, 
somente uma obra preocupada em analisar a abordagem da situação do campo brasileiro pelo periódico. Enilce Souza analisou, a partir das edições de 1963 e 1964, a posição d'O Nordeste acerca dos debates sobre reforma agrária, êxodo rural, conflitos rurais e reformas de base. Apesar da aparente semelhança, nossa pesquisa partiu de recorte e indagações diferentes dos utilizados pela autora, que concentrou sua análise no tratamento das reformas de base e do êxodo rural.

Até o início da atuação sistemática da Igreja no campo por meio do MEB, raras foram as notícias associadas às questões sociais rurais e ao papel político do trabalhador rural. A análise dos problemas do campo tinha como eixo a questão agrícola ${ }^{51}$, defendendo a mecanização da agricultura, a redefinição das políticas de créditos, o incentivo à formação técnica dos trabalhadores rurais e a preocupação com a erosão do solo. $\mathrm{O}$ artigo publicado na coluna "Endereço Certo" ilustra essa interpretação dos problemas rurais. Nesse artigo, Al. Neto apontou a deficitária política creditícia brasileira e a incapacidade técnica dos produtores como as causas dos problemas rurais, que, por sua vez, eram resumidos a incapacidade produtiva das propriedades rurais. Segundo o autor, "a agricultura é, hoje em dia, ciência complexa, que exige os serviços do profissional competentemente treinado" ${ }^{~} 52$, e a política de concessão de créditos não levava isso em consideração ao conceder crédito a qualquer pequeno produtor. Essa prática estaria provocando a erosão do solo e o desperdício de recursos, pois a incapacidade técnica dos produtores não os permitia produzir de forma adequada a trazer resultados satisfatórios. Outro exemplo de análise sobre a incapacidade técnica dos trabalhadores rurais é o artigo "Interesse pelo Nordeste", no qual o incentivo à vinda de imigrantes qualificados foi sinalizado como solução para os problemas do Nordeste, uma vez que auxiliariam na formação endógena de profissionais especializados no trato da terra e no manuseio de máquinas. Além de contribuírem para o aumento da produtividade agrícola, esses profissionais nacionais engrossariam a "classe média", interpretada, ao exemplo da Pastoral Coletiva, como a classe capaz de conter o comunismo ${ }^{53}$.

A mecanização da produção rural também era apresentada como a principal barreira à expansão do comunismo. Por exemplo, de acordo com o artigo "Know How”, a mecanização da produção agrícola, ao desenvolver a agricultura, contribuiria para a superação da pobreza da população rural. Tal superação, ao aumentar o poder de consumo dos trabalhadores rurais, ampliaria o mercado interno de bem manufaturados, o que levaria à expansão da indústria nacional. Além de reproduzir ideias desenvolvimentistas, o artigo compartilhava da premissa governamental estadunidense de que o comunismo só floresceria onde existisse pobreza, 
defendendo que a melhora das condições socioeconômicas da população rural retiraria as justificativas materiais de apoio ao comunismo ${ }^{54}$.

O combate ao comunismo também foi a base da proposta de reforma agrária apresentada pelo jornal nos primeiros meses do ano. Em concordância com a estratégia argumentativa do periódico de utilizar linguagem simples e textos curtos e diretos, a elaboração desse complexo conceito foi sucinta. No artigo "A Reforma Agrária”, J. S. Nogueira defendeu que esta seria a principal arma contra a expansão do comunismo ${ }^{55}$, pois resolveria "o problema social na vida do campo conforme adverte o episcopado" proposta era clara: não seria apenas redistribuição de terras, mas sim um projeto de concessão de créditos e de educação técnica orientado pelo Estado. Entretanto, alertava para a necessidade de problematizar o grau da autonomia estatal, pois, quando orientada pelo Estado ou fruto de uma ação revolucionária, a reforma agrária poderia tomar contornos "ditatoriais", como ocorrera na China, na URSS e em Cuba.

A questão técnica também foi utilizada para discutir a seca, classificada, única e exclusivamente, como natural ${ }^{57}$. O caminho sinalizado para a superação dessa mazela não poderia ser outro senão as "experiências vitoriosas da ciência", em especial o desenvolvimento da engenharia hidráulica ${ }^{58}$. Tal argumento se aproximava do discurso dos latifundiários, que utilizavam essa ideia de fatalidade climática para, nos momentos de estiagem, se beneficiarem de isenção fiscal, crédito bancário e auxílios financeiros concedidos pelo governo federal ${ }^{59}$.

Scott Mainwaring atentou para a problema de analisar a Igreja como somente preocupada em interferir na estrutura política da sociedade ou como essencialmente voltada para a propagação da sua mensagem religiosa. Segundo o autor, devemos fazer um jogo de escalas, analisando a Igreja como uma instituição que busca, ao mesmo tempo, intervir na estrutura política da sociedade e pregar sua mensagem religiosa, sendo a ênfase em um desses caminhos orientada por conflitos endógenos e exógenos. Tal análise nos ajuda entender outra característica discursiva d'O Nordeste. A forma de tratar os problemas rurais não era baseada exclusivamente em orientações políticas e a apologia à questão técnica era superada quando os "direitos humanos" eram preteridos ${ }^{60}$, ao exemplo do artigo "Providência Indispensável", no qual a atuação do Deputado Wilson Roriz contra os impactos socioambientais da construção da barragem de Orós sobre a população da cidade de Iguatu foi congratulada ${ }^{61}$.

Logo após a Igreja lançar o MEB, essa forma de analisar os problemas do campo brasileiro sofreu expressiva alteração. A preocupação transmuta da questão técnica para a questão socioeconômica, pois o foco no homem rural "deveria constituir objetivo de toda a 
política agrária"62. Dois textos simbolizam essa mudança: "Desenvolvimento" e "Manifestase a Lavoura". Por incrível que pareça, o primeiro artigo é uma contundente crítica àqueles que analisaram o desenvolvimento brasileiro única e exclusivamente pelo viés técnico. $\mathrm{O}$ texto é categórico ao afirmar que o "desenvolvimento econômico é principalmente humano" e que só seria alcançado por meio da educação do povo, pois "enquanto formamos uma nação com alto coeficiente de analfabetismo não poderemos em hipótese alguma ser uma nação desenvolvida"63. O artigo "Manifesta-se a Lavoura", por sua vez, é uma crítica ao modo pelo qual a Confederação Rural Brasileira interpretou o campo brasileiro da década de 1960. "Como se vê, mostra-se a Confederação inteiramente à margem dos verdadeiros problemas da nossa agricultura, o que demonstra à sociedade que sua direção é composta de medalhões de todo alheios às necessidades do ruralismo nacional" "64. Continua: não detêm conhecimento algum "das necessidades do homem e da terra em nosso País" e "acham de manifestar-se

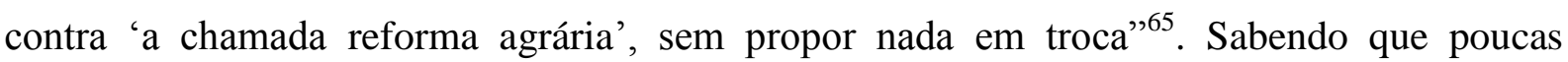
edições antes, o jornal, em concordância com o argumento do episcopado, defendia a atuação dos setores patronais na viabilização da reforma agrária, tal artigo representou considerável mudança, evidenciando a tentativa de dissociar o catolicismo das forças conservadoras e se mostrar preocupado com as injustiças da sociedade capitalista.

A forma de tratar a reforma agrária também sofreu importante modificação. Como vimos, a proposta defendida pelo jornal se resumia à concessão de créditos e promoção da educação técnica. A partir de março, o problema do campo não era mais associado ao aspecto técnico, e sim ao "subdesenvolvimento" e à pobreza. Dessa forma, se aproximando do argumento episcopal, $O$ Nordeste passou a defender uma reforma pautada no acesso da população rural à previdência social, assistência médica, educação e saúde pública ${ }^{66}$, enfatizando seu papel no controle do êxodo rural $^{67}$ e, consequentemente, da formação de favelas, como foi possível perceber nas, então, corriqueiras notícias sobre o tema. Ademais, reforçava críticas às propostas de modificações da estrutura agrária a partir da luta de classes - como era defendido pelo PCB e pelas Ligas ${ }^{68}$.

Ainda nesse contexto de alteração argumentativa, o jornal se preocupou em apresentar a gênese dos problemas rurais brasileiros para além da educação técnica, identificando-os como resultados de um processo histórico. Se aproximando das teorias apresentadas por autores pecebistas - como Alberto Passos Guimarães e Moisés Vinhas ${ }^{69}$, O Nordeste destacou que a origem do problema rural brasileiro estava na colonização, quando foram implantadas as sesmarias, política de acesso a terra que lançou as bases para a concentração fundiária e exploração "semifeudal" dos trabalhadores rurais. 
Após março de 1961, O Nordeste assumiu características panfletárias, orientando e informando sobre as principais ações e diretrizes da Igreja Católica no campo. Essa propaganda consistia na publicação de entrevistas dos representantes do episcopado brasileiro, como D. Antônio Fragoso, D. Hélder Câmara e Dom Vicente Scherer, que apresentavam a Igreja preocupada com a "promoção do nível social das populações do campo e da cidade" ${ }^{70}$ e tentavam justificar as intervenções da Igreja nas questões socioeconômicas como primordial à eficácia da evangelização. Havia também a legitimação da educação enquanto instrumento de transformação social, noticiando a atuação do MEB e os encontros da Juventude Estudantil Católica e da Associação de Educadores Cristãos, criando as colunas fixas "Acontecimentos Estudantis" e "Universidades e Universitários" e fornecendo importante destaque à figura dos professores e monitores do $\mathrm{MEB}$, em substituição à figura do engenheiro, até então apresentada como símbolo da resolução dos problemas rurais.

Nas edições de 1962, o trato dos problemas rurais permaneceu alinhavado aos argumentos do episcopado brasileiro. Compartilhando das proposições defendidas pelo MEB e pela encíclica Mater et Magistra (1961), o periódico passou a enfatizar a formação de líderes rurais, argumentando que os problemas do campo deveriam ser pensados por pessoas que dependiam do campo para subsistir, e não por "burgueses e aburguesados, sem nenhuma vinculação com as massas"71, que utilizavam a população rural para conquistar cargos na assembleia legislativa e nas administrações estaduais e municipais. A apologia ao cooperativismo também estava presente nessas edições. A formação de cooperativas era apresentada como a melhor forma de extirpar as "práticas maléficas da sociedade no terreno econômico" "72 em um "país sem leis agrárias"73. Nada mais adequado a uma interpretação da realidade brasileira que destacou a miséria como o principal problema agrário brasileiro.

Apesar de algumas notícias tratarem da formação de líderes rurais, e do cooperativismo possuir uma coluna fixa no Suplemento Dominical do O Nordeste $(\mathrm{SDON})^{74}$, a questão mais abordada nas edições de 1962 foi a sindicalização dos trabalhadores rurais. Em 1962, a promulgação das portarias $\mathrm{n}^{\circ} 209-\mathrm{A} / 25$ e $355-\mathrm{A}$, que regulamentavam o sindicalismo rural no Brasil, proporcionou "uma verdadeira corrida pela formação de sindicatos de trabalhadores rurais no país" ${ }^{\text {75 }}$. Nessa corrida, a Igreja Católica foi favorecida pela relação tecida com o ministro do trabalho André Franco Montoro (setembro de 1961 - julho de 1962), filiado ao Partido Democrata Cristão e responsável pelo reconhecimento de cerca de 70 sindicatos católicos, em sua maioria associados aos círculos operários católicos ${ }^{76}$. A ação dos prepostos católicos no Ceará, durante o ano de 1962, também nos permite melhor compreender essa escolha editorial: a intensificação dos esforços da Federação dos Círculos 
Operários em conquistar cada vez mais trabalhadores para as bases católicas; a criação dos sindicatos de Crato, Juazeiro do Norte, Barbalha, Brejo Santo e Várzea Alegre - que faziam parte do projeto da Igreja de formar uma Federação, para assim melhor disputar a direção da Confederação Nacional dos Trabalhadores Agrícolas (CONTAG) ${ }^{77}$; a concepção do movimento Trabalhador Unido, organizado e orientado pelo movimento circulista como uma tentativa dos setores conservadores de ampliar suas bases no movimento sindical urbano e rural frente à atuação de um adversário comum, os comunistas ${ }^{78}$.

A organização sindical católica não era homogênea. No interior do movimento existiam setores conservadores - compostos pelos Círculos Operários, pelo Serviço de Assistência Rural (SAR) e pelo SORPE - e progressistas, compostos pela Ação Popular (AP). As forças conservadoras tratavam a questão sindical como questão social, focalizando: a formação de lideranças; a harmonização das relações entre governo, posseiros e grileiros; a assistência educacional, espiritual, sanitária e técnico-financeira; e a propagação do cooperativismo rural. A Ação Popular, por sua vez, ia na contramão dessas proposições. Resultado de um desmembramento da Juventude Universitária Católica, a AP foi criada em 1962 e logo se definiu pelo socialismo e pelo apoio às lutas dos camponeses. Diferentemente dos setores conservadores, a AP não apontava a fome ou a questão técnica como os problemas da população rural, mas sim a dominação feudal e imperialista no Brasil, as disparidades regionais e a propriedade privada. Essa diferença se fez clara durante a formação da primeira diretoria da CONTAG, convocada após as duas tentativas da hierarquia católica de controlar unilateralmente a formação dessa confederação. A Ação Popular, que possuía três cargos a sua disposição, firmou um acordo com o PCB, que dispunha de quatro cargos, para isolar as lideranças dos círculos operários, que contavam com dois cargos, e assim evitar a formação de uma diretoria "cristã-conservadora"79.

Após a Igreja assumir a sindicalização como eixo de atuação no meio rural, o jornal passou a publicar editais de convocação para as assembleias dos sindicatos rurais católicos de Fortaleza ${ }^{80} \mathrm{e}$ a fornecer orientações sindicais aos trabalhadores rurais, explicando o que é um sindicato, qual o regime sindical brasileiro e a diferença entre o sindicato e a associação profissional $^{81}$, além de publicar entrevistas com bispos, padres e assistentes sociais responsáveis pela sindicalização do trabalhador rural. Aproximando-se da concepção sindical cristã-conservadora, essas notícias repudiavam a politização dos sindicatos ${ }^{82}$, apresentando o sindicato católico como somente preocupado com a transformação da mentalidade do homem do campo, estimulando-o a enxergar a vida comunitária como meio de defesa dos seus interesses e promoção da justiça social ${ }^{83}$. 
Para estimular a organização dos trabalhadores rurais em torno dos sindicatos católicos o periódico adotou duas estruturas argumentativas. A primeira consistia na apresentação dos ganhos materiais que a luta por meio dos sindicatos poderia trazer, enfatizando os ganhos salariais, as melhores condições de trabalho e o aumento da produtividade, "sem a qual o aumento monetário de salários, torna-se meramente, fontes de inflação" ${ }^{84}$. Outra forma de estimular a adesão ao sindicalismo era demonstrar sua legalidade por meio da publicação do decreto-lei 7.038, de 10 de dezembro de 1944 que, segundo o periódico, previa a fundação de sindicatos no campo. Essa estratégia está relacionada ao fato dos trabalhadores rurais buscarem atuar dentro da legalidade, podendo essa ser baseada nos costumes ou nas palavras da lei. Como demonstraram Clifford Welch e Fernando Teixeira Silva, os trabalhadores rurais brasileiros, apesar de tratarem com parcimônia os efeitos da lei e da Justiça do Trabalho, idealizavam a efetivação e a aplicação da legislação enquanto garantidora de seus direitos, por isso adotavam a legalidade como princípio norteador de suas ações. Sabendo dessas características, o jornal tentava apresentar a legalidade da luta sindical em contraposição à "ilegalidade" da Liga Camponesa e do PCB. A fala de Teixeira Silva resume bem a estratégia argumentativa do periódico:

\footnotetext{
Se lermos com cuidado essas declarações, poderemos constatar que não apenas os ativistas eram responsáveis por fazer os trabalhadores rurais conhecerem seus direitos, como também eram estes que mostravam àqueles que a questão legal e mesmo jurídica era um valor cultural de primeira grandeza ${ }^{85}$.
}

Ainda com relação à abordagem da questão sindical, preocupado, mais uma vez, em não alimentar qualquer caracterização da Igreja como uma instituição dotada de projetos políticos, O Nordeste buscava apresentar a possibilidade do uso "harmonioso" e apolítico dos sindicatos por todos aqueles preocupados em promover mudanças sociais no campo - abrindo caminho para classificar o uso político dos sindicatos, por movimentos pautados em referenciais marxistas, como uma deturpação do seu verdadeiro objetivo. Para tanto, atentava para a aceitação da sindicalização por parte dos proprietários rurais, destacando a possível fundação de cem sindicatos de proprietários rurais, no ano de $1963^{86}$.

\section{De rurícola a camponês}

O patronato rural, interessado em combater a sindicalização classista e deslegitimar qualquer organização política dos trabalhadores rurais, associava rurícola à ingênuo, sinalizando que estes seriam facilmente coagidos por forças interessadas em reproduzir conflitos de classe exclusivos à cidade ${ }^{87}$. Ademais, utilizavam o termo para adjetivar a 
incapacidade técnica dos trabalhadores rurais e deslegitimar qualquer proposta de interpretação dos problemas do campo a partir da concentração fundiária, pois defendiam que a improdutividade rural estava relacionada, única e exclusivamente, a essa incapacidade. Nas primeiras edições de 1961, O Nordeste se aproximava dessa caracterização, e tratava o homem rural como "rurícola", "sertanejo", "agricultor" ou "lavrador pobre". A mudança no tratamento da população rural está intimamente relacionada à modificação na interpretação dos problemas rurais - trabalhada nos tópicos anteriores. A partir da sistematização da atuação da Igreja no campo, foi possível observar, somado a esses termos, a utilização do termo "camponês". O uso desse termo, pelo periódico, demonstra a caracterização dos trabalhadores do campo como atores políticos, reconhecendo-os como agentes da transformação do campo.

A sistematização da atuação da Igreja no campo não somente mudou a forma de se referir ao trabalhador rural, mas também o seu papel no periódico. O jornal passou a ter colunas fixas relacionadas ao interior cearense, como: a "Iguatu em Revista" 88 e a "Interior em Foco", que publicavam, em tom de denúncia e reclamação, notícias referentes à situação dos trabalhadores rurais que lá viviam; e "O nordeste agrícola" 89 , que fornecia orientações agropecuárias, por exemplo, os cuidados destinados a um bezerro recém-nascido, ao solo ${ }^{90} \mathrm{e}$ às máquinas agrícolas ${ }^{91}$. Nessas colunas, e também em outras partes, o jornal publicava: anúncios sobre a venda de materiais agropecuários ${ }^{92}$; orientações sobre a concessão de financiamento pela carteira agrícola do Banco do Brasil ${ }^{93}$; informes sobre as mudanças organizativas dos círculos operários que tinham atuação frente aos trabalhadores rurais; editais de convocações para as assembleias gerais e reuniões dos sindicatos rurais do Ceará ${ }^{94}$; e, sempre que oportuno, a indicação de livros sobre reforma agrária, em especial a obra "Reforma Agrária: Questão de Consciência", apresentada como referência para pensar o tema dentro da doutrina social. Como destacaram Cruz e Peixoto, a existência de colunas fixas e suplementos indicam a abertura de espaço para interesses de grupos específicos, nesse caso um grupo que passou a ter papel primordial nos rumos políticos do país e, por isso, disputado pela Igreja, pelas Ligas Camponesas e pelo PCB. O conteúdo dessas notícias também nos permite destacar que os setores alvo da suas estratégias argumentativas eram os assalariados agrícolas, como o foco na questão sindical e o anúncio das assembleias circulistas nos permitem intuir, e os pequenos e médios proprietários, como sugere o tipo de equipamento anunciado nos classificados do periódico - o micro-trator 'Tobatta' -, a criação de uma coluna voltada à cooperativa e o anúncio das políticas de crédito bancário, que posseiros, agregados, meeiros e foreiros não teriam acesso. 
Uma pergunta surge: quais os critérios utilizados para definir, a partir de março de 1961, o homem rural como "rurícola" ou "camponês"? O conceito de "camponês" é fruto de discussão e imprecisão desde a década de 1920, quando o PCB introduziu o termo para caracterizar a população rural. O próprio partido (aqui estamos considerando as diretrizes elaboradas em seus congressos, sua imprensa e sua produção teórica) lançou mão de diferentes definições e usos do conceito, mas, em linhas gerais, a partir do seu terceiro congresso (1928) o conceito assumiu caráter político e sociológico ${ }^{95}$. O Nordeste refletiu essa característica ao associar o termo camponês à forma de luta da população rural, quando estavam "dispostos a exigir obrigações do governo com a Democracia"96, ou seja, na ocasião em que lutavam baseados nos princípios defendidos pela Igreja eram camponeses. Já o termo "rurícola" era utilizado para definir aqueles que não lutavam ou não se enquadravam nas doutrinas sociais da Igreja ${ }^{97}$. Além disso, relembrando os discursos católicos contra a escravização indígena, esses "rurícolas" também eram tratados como "ingênuos"98, "facilmente manipulados" "99 "cobaias de subversão da ordem"100 e enganados pelos "aproveitadores da miséria das massas"101.

Além de transformar-se em importante público alvo, a opinião da população rural passou a ser usada para legitimar os argumentos do periódico, como demonstram os artigos "Encerrado o congresso operário cristão nacional"102, "O que reclamam os agricultores nordestinos"103 e "Conheça os fabricadores do comunismo" 104 . Na notícia "O que reclamam os Agricultores Nordestinos" o jornal utilizou a opinião dos próprios trabalhadores rurais, representados na figura de "Caio Lins Cavalcanti - presidente da Associação dos Pequenos Agricultores, que congrega mais de 3.500 sócios"105, para condenar as ações das Ligas Camponesas. Já na notícia "Encerrado o congresso operário cristão nacional”, o jornal legitimou as ações da Igreja no campo a partir da opinião do trabalhador João do Amaral, que, no discurso de encerramento desse congresso, agradeceu e reconheceu as ações dos padres: "acontecem coisas incríveis em Guariba; há latifundiários que chegam a proibir que trabalhadores assistam missa, porque o padre condena a exploração e ensina o camponês a defender-se" "106. Na notícia "Conheça os fabricadores do comunismo"107, o argumento dos "lavradores da Média Mogiana” foi utilizado para criticar e identificar um adversário, os intermediários, que, resultantes da "economia pré-capitalista ou pseudo-capitalista"108 brasileira, contribuíam para a exploração da população rural.

Apesar de ser foco e de ser utilizado como legitimador das informações oferecidas pelo jornal, em raros momentos os trabalhadores rurais possuíam voz ativa no mesmo. Nesse sentido, $O$ Nordeste diferencia-se dos demais periódicos voltados exclusivamente aos 
trabalhadores rurais, em especial o Terra Livre e o Liga, que, como destacou Enilce Souza, também eram instrumentos de manifestação dos camponeses. Como destacou a autora, não era característica da grande imprensa "ontem como hoje, pautar as lutas sociais, do ponto de vista dos seus protagonistas, ou mesmo, dando a conhecer ao leitor as várias faces dos conflitos sociais e da luta pela terra no Brasil" ${ }^{\prime 109}$.

\section{Principais pontos a serem retidos}

Ao apresentar o campo como um local harmonioso e caracterizado pela paz social, $O$ Nordeste alinhava-se ao silêncio da "grande imprensa" sobre a violência no campo. Esta paz só era incomodada pelos movimentos subversivos, em especial as Ligas Camponesas, que atuavam no campo brasileiro se aproveitando da fragilidade e da falta de consciência dos trabalhadores rurais. Tal interpretação refletia a visão episcopal predominante, evidenciando ser $O$ Nordeste um periódico alinhavado com as diretrizes da hierarquia católica. Quando esta defendeu a resolução dos problemas rurais por meio de soluções técnicas, o jornal destacou o papel dos engenheiros e do ensino técnico, como fundamentais para a contenção do comunismo. Quando o episcopado passou a incentivar a mobilização da população rural, o periódico retratou-a como camponesa e destacou o papel transformador da educação de base e da reforma agrária assistencial.

Com relação à estrutura argumentativa do periódico, a estratégia consistia em analisar os problemas rurais de forma simples e capaz de transmitir segurança à população rural, elegendo um adversário (a seca/o comunismo), um problema (a incapacidade técnica/a pobreza) e uma solução (o ensino técnico/a educação de base). Ademais, suas estratégias argumentativas tanto eram voltadas aos trabalhadores rurais como à opinião pública preocupado em esvaziar qualquer constatação de ações políticas da Igreja.

O Nordeste ora caracterizava o homem rural como "camponês" ora como "sertanejo", "rurícola", "agricultor" ou "lavrador pobre". A utilização do termo camponês estava associada à forma de luta empregada, quando baseada nos princípios defendidos pela Igreja, os agentes eram classificados como camponeses. Já o termo "rurícola" era utilizado para definir aqueles que não lutavam ou não se enquadravam nas doutrinas sociais da Igreja. Relacionado a esse aspecto, o periódico não teceu quaisquer críticas às ações dos trabalhadores rurais, somente às forças "articuladoras" e/ou "aproveitadoras". Essa caracterização tem fundamento em uma interpretação dúbia, ao mesmo tempo em que os reconheciam como atores políticos, 
consideravam que não estavam conscientes das condições de sua exploração, por essa razão, poderiam ser utilizados por outras forças sociais.

Os discursos pecebistas tiveram significativa eloquência no meio rural, produzindo, inclusive, um contexto linguístico, determinante na organização das retóricas e maneiras de falar sobre política. No nosso objeto, isso se representa na utilização do conceito de camponês como categoria política e sociológica, e na definição do campo brasileiro como "semifeudal".

\section{Notas}

${ }^{1}$ CARVALHO, Abdias Vilar de. A Igreja católica e a questão agrária. In: PAIVA, Vanilda. Igreja e questão agrária. São Paulo: Loyola, 1985, p.70.

${ }^{2}$ Ibidem, p. 72-78.

${ }^{3}$ MEDEIROS, Leonilde. Movimentos Sociais no Campo, Lutas por Direitos e Reforma Agrária na Segunda Metade do Século XX. In: CARTER, Miguel (Org.). Combatendo a Desigualdade Social: o MST e a Reforma Agrária no Brasil. Tradução de Cristina Yamagami. São Paulo: Editora UNESP, 2010, p.116.

${ }^{4}$ CARVALHO, op. cit., p. 78-92; 102-103.

${ }^{5}$ DELGADO, Jaime Ornelas. Volver al desarrollo. Problemas del Desarrollo, Cidade do México, v. 43, n. 168 , jan./mar. 2012, p. 7-35.

${ }^{6}$ MOREIRA, Vânia Losada. Nacionalismos e reforma agrária nos anos 50. Revista Brasileira de História, São Paulo, v. 18, n. 35, p. 329-360, 1998, passim.

${ }^{7}$ SINGER, Paul. Interpretação do Brasil: uma experiência histórica de desenvolvimento. In: FAUSTO, Boris (dir.) História Geral da Civilização Brasileira: o Brasil Republicano. Economia e Cultura. São Paulo: DIFEL, 1984, 4 v., p. 227-228.

${ }^{8}$ RODRIGUES, Fabiana de Cássia. O papel da questão agrária no desenvolvimento do capitalismo nacional, entre 1950 e 1964, em Caio Prado Jr., Celso Furtado, Ignácio Rangel e autores pecebistas. Dissertação de mestrado, Economia, Instituto de Economia, UNICAMP, 2005, p.34-35.

${ }^{9}$ MARTINS, José de Souza. Os camponeses e a política no Brasil: as lutas sociais no campo e seu lugar no processo político. 2. ed. Petrópolis: Vozes, 1983. p. 67-80.

${ }^{10} \mathrm{~A}$ aproximação com o Ponto IV não ocorreu somente na esfera discursiva. O Movimento Sindical Democrático, em que membros dos Círculos Operários militavam, obteve apoio do programa estadunidense. Cf. RICCI, Rudá. Terra de Ninguém: representação sindical rural no Brasil. Campinas: Editora da Unicamp, 1999, p. 59-60.

${ }^{11}$ CARVALHO, op. cit., p. 79-81.

${ }^{12}$ Ibidem, p. 83-84.

${ }^{13}$ Em 1950, Getúlio Vargas buscava incorporar a questão agrária ao cerne do processo de avanço da indústria no país. Segundo Vargas, o campo deveria fornecer alimentos e matérias-primas para a indústria. E isso só seria possível com a resolução de quatro problemas: a) insuficiência de crédito; b) a ausência de técnicas "modernas"; c) a falta de organizações associativas; d) o êxodo rural. Para auxiliar, gerenciar e efetivar essas mudanças, Vargas criou, em 1951, a CNPA. Essa era uma comissão interministerial subordinada ao poder imediato do presidente - ou seja, sem muita autonomia -, cujo objetivo principal era apresentar ao presidente da república as medidas necessárias para o desenvolvimento da economia agrícola. A principal ação da CNPA foi a elaboração de um projeto de reforma agrária. Na tentativa de evitar que resistências a questões pontuais parassem o projeto, a CNPA propôs diversas diretrizes. Essas diretrizes tinham como eixos o parágrafo 147 - que previa o uso da propriedade condicionado ao bem estar social -, o combate à proletarização do camponês, as peculiaridades regionais, o papel produtor e social da pequena propriedade e, é claro, o fornecimento de alimentos. Faziam parte da CNPA: o Instituto de Imigração e Colonização, a Carteira de Colonização do Banco do Brasil, o Banco Nacional de Crédito Cooperativo, a Companhia Nacional de Seguros Agrícolas, o Conselho Nacional de Administração de Empréstimos Rurais e o Serviço Social Rural. Cf. TAPIA, Jorge. Capitalismo e questão agrária: um estudo sobre as alternativas para a Reforma Agrária no Brasil (1946-64). Tese de mestrado, Ciência Política, IFCH, Unicamp, 1986, p. 189-192; MEDEIROS, Leonilde Servolo de. A questão da reforma agrária no Brasil. Dissertação de mestrado, Ciência Política, FFLCH, USP, 1983, p. 104.

${ }^{14}$ Esse artigo previa a desapropriação por utilidade pública ou interesse social mediante justa indenização em dinheiro. Alguns autores, como Jorge Tapia, consideraram o $\$ 16$ do artigo 141 um avanço no que diz respeito ao trato da questão agrária, pois possibilitava que o Estado interviesse no "sagrado" direito da propriedade privada. 
Porém, nos aproximamos mais da análise desenvolvida por Medeiros, na dissertação A questão da reforma agrária no Brasil, que considerou tal artigo uma atitude de salvaguarda dos representantes do patronato rural deputados Masagão (UDN-SP), Prado Kelly (UDN- SP) e Costa Souza (PSD-RS) -, preocupados com as ideias que circulavam na sociedade brasileira e expressavam-se na constituinte de 1946, conseguindo evitar a atuação sistemática do Estado em prol da reforma agrária, mantendo preservados o sistema de poder e propriedade no campo, além disso, demarcaram a atuação das lutas daqueles que pretendiam realizar uma reforma agrária legalista, pois tinham como baliza inicial proposições de emendas constitucionais ao referido artigo, no intuito de contorná-lo.

${ }^{15}$ CNBB apud CARVALHO, op. cit., p. 86.

${ }^{16}$ No documento A Igreja e a Reforma Agrária (1954), a reforma agrária, com base na propriedade privada, novamente é apresentada como a forma de fixar o homem rural no campo. Cf. CARVALHO, Op. cit., p. 87-89.

${ }^{17}$ Ibidem, p. 89-92.

${ }^{18}$ CNBB apud CARVALHO, op. cit., p. 86.

19 FÁVERO, Osmar. Uma pedagogia da participação popular: análise da prática pedagógica do MEB Movimento de Educação de Base, 1961-1966. Campinas: Autores Associados, 2006, p.39.

${ }^{20}$ ALVES, Márcio Moreira. A Igreja e a Política no Brasil. São Paulo: Editora Brasiliense, 1979, p.71-72.

${ }^{21}$ CARVALHO, op. cit., p.97.

${ }^{22}$ As escolas radiofônicas do Serviço de Assistência Rural (SAR) criadas por D. Eugênio Sales - após conhecer pessoalmente o funcionamento das escolas radiofônicas colombianas -, com o objetivo de promover a alfabetização de jovens e adultos das áreas rurais de Natal. Esse sistema serviu de base para a introdução do MEB/Natal. Cf. PAIVA, Marlúcia Menezes (Org.). Escolas radiofônicas de Natal: uma história construída por muitos (1958-1966). Brasília: Liber Livro, 2009, p. 63.

${ }^{23}$ MENDONÇA, Sônia Regina. Estado, Educação Rural e Influência Norte-Americana: 1930-1961. Niterói: Editora da UFF, 2010, passim.

${ }^{24}$ RICCI, op. cit., p. 56.

${ }^{25}$ Apesar de romper com outras formas de inferiorização do trabalhador rural, o MEB ainda os considerava inferiores politicamente. As Ligas Camponesas e o PCB, partindo dos pressupostos marxistas, também compartilhavam dessa interpretação do trabalhador rural, reforçando a posição dos trabalhadores urbanos como vanguarda da luta revolucionária.

${ }^{26}$ KADT, Emanuel. Católicos Radicais no Brasil. Brasília, DF: UNESCO/MEC, 2007, p.129-134.

${ }^{27}$ FÁVERO, op. cit., p.6.

${ }^{28}$ Idem.

${ }^{29}$ Quando o programa Voz do Brasil passou a ser transmitido das $19 \mathrm{~h}$ às $20 \mathrm{~h}$ - antes, o programa ocupava o horário das $19 \mathrm{~h} 30$ às $20 \mathrm{~h} \mathrm{-,} \mathrm{as} \mathrm{aulas} \mathrm{do} \mathrm{primeiro} \mathrm{ciclo,} \mathrm{que} \mathrm{aconteciam} \mathrm{de} 18 \mathrm{~h} 30$ às $19 \mathrm{~h} 30$, e as do segundo ciclo, veiculadas de $20 \mathrm{~h}$ às $20 \mathrm{~h} 30$, foram reorganizadas para horários que não agradaram a população rural. Cf. FÁVERO, op. cit., p. 149-150.

30 Após alguns anos utilizando o know hall acumulado na educação de jovens e adultos para fornecer consultorias e cursos de capacitação às instituições educacionais brasileiras, na década de 1970 o MEB restabeleceu-se frente à população rural, com novos temas e proposições. Essa retomada se insere no ressurgimento, durante as décadas de 1970 e 1980, do caráter nacional das lutas pela terra. Hoje, o movimento está presente em seis estados - São Paulo, Piauí, Maranhão, Ceará, Rio Grande do Norte e Alagoas - e no Distrito Federal.

${ }^{31}$ ECKERT, Cordula. O Master e as ocupações de terra no Rio Grande do Sul In: MEDEIROS, Leonilde Servolo; PAULILO, Maria Ignez; FERNANDES, Bernardo Mançano (Orgs.). Lutas camponesas contemporâneas: condições, dilemas e conquistas. São Paulo: Editora UNESP; Brasília, DF: Núcleo de Estudos Agrários e Desenvolvimento Rural, 2009, 1 v., p. 73-76.

${ }^{32}$ RICCI, op. cit., p. 62.

${ }^{33}$ WELCH, Clifford Andrew. A Semente foi plantada: as raízes paulistas do movimento sindical camponês no Brasil, 1924-64. São Paulo: Expressão Popular, 2010, p.326.

${ }^{34}$ MEDEIROS, Leonilde Servolo de. A questão da reforma agrária no Brasil, p. 58-59.

${ }^{35}$ GRYNSZPAN, Mário. Mobilização camponesa e competição política no Estado do Rio de Janeiro (19501964). Dissertação de mestrado, Antropologia Social, Museu Nacional, UFRJ 1987, p. 253-261.

${ }^{36}$ ALBUQUERQUE, Ronald de Figueiredo. Igreja, Sindicato e organização dos trabalhadores. Dissertação de mestrado, Sociologia do Desenvolvimento, Centro de Humanidades, UFC, 1991, p.102.

${ }^{37}$ SOUZA, Enilce Lima Cavalcante. Campo e palavras: dimensões da questão agrária no Ceará, 1954-64.

Dissertação de mestrado, História Social, Centro de Humanidades, UFC, 2005, p. 99.

${ }^{38}$ Ibidem, p.88.

${ }^{39}$ ALBUQUERQUE, op. cit., p. 102-103.

${ }^{40}$ Ibidem, p. 103 
${ }^{41}$ SANTOS, Jovelina Silva. Círculos Operários no Ceará: "instruindo, educando, orientando e moralizando" (1915-63). Dissertação de mestrado, História Social, Centro de Humanidades, UFC, 2004, p.57.

${ }_{42}$ Ibidem, p.98-102.

${ }^{43}$ ALBUQUERQUE, op. cit., p.123.

${ }^{44}$ Compartilhando da definição empreendida por Medeiros, na tese Lavradores, trabalhadores agrícolas, camponeses: os comunistas e a constituição de classes no campo, utilizamos esse conceito com a intenção de englobar todos os atores que atuavam no mundo do trabalho rural: "foreiros", "pequenos proprietários", "meeiros", "parceiros", "vaqueiros", "posseiros", "condiceiros" e "assalariados agrícolas".

${ }^{45}$ No decorrer de 1961, Padre Tarcísio de Almeida assumiu a função de redator secretário e Murilo Ribeiro Cavalcante a de gerente. Em 1962 o expediente sofreu as seguintes alterações, que se mantiveram até 1964: Diretor, Mons. André V. Camurça; Secretário, Pe. Tarcisio S. Almeida; Gerente, Murilo Cavalcanti; Secretario de Redação, Helder Feitosa; Diretor de Publicidade, Jairo Mota.

${ }^{46}$ O Nordeste, 3/3/1961, p.1.

${ }^{47}$ O Nordeste, 18/4/1961, p. 1.

${ }^{48} \mathrm{O}$ periódico conclamou comerciantes e industriais a não abrirem seus estabelecimentos no Dia de Reis. Cf. $O$ Nordeste, 4/1/1961, p.1.

${ }^{49} \mathrm{O}$ periódico publicava notícias sobre as faculdades cearenses, em especial a Escola de Agronomia.

${ }^{50}$ Identificamos a publicação de convocações para a Assembleia Geral Ordinária da OAB - CE.

${ }^{51}$ Quando nos referimos à questão agrícola estamos tratando de onde, quanto e o que se produz. E quando nos referimos à questão agrária, estamos abordando temas ligados às relações de trabalho e exploração, à estrutura fundiária e às formas de produção.

${ }^{52} O$ Nordeste, 2/1/1961, p.5.

${ }_{53}$ O Nordeste, $1 / 2 / 1961$, p. 3.

${ }^{54}$ O Nordeste, 23/1/1961, p.5.

${ }^{55}$ O Nordeste, $3 / 1 / 1961$, p.4.

${ }^{56}$ O Nordeste, 25/1/1961, p. 3.

${ }^{57}$ O Nordeste, 20/5/1961, p.7.

${ }^{58}$ O Nordeste, 18/1/1961, p.1.

${ }^{59}$ AZEVÊDO, Fernando Antônio. As Ligas Camponesas. Rio de Janeiro: Paz e Terra, 1982, p. 63-64.

${ }^{60} \mathrm{~A}$ partir de 1945 os direitos humanos foram associados à universalidade do direito à existência, à integridade física e moral da pessoa, à vida e à não-discriminação. Cf. MBAYA, Etienne-Richard. Gênese, evolução e universalidade dos direitos humanos frente à diversidade de culturas. Estudos Avançados. v. 11, n. 30, 1997 p. 2.

${ }^{61} O$ Nordeste, 2/2/1961, p.3.

${ }^{62} O$ Nordeste, 28/3/1961, p. 5.

${ }^{63}$ O Nordeste, 20/3/1961, p.2.

${ }_{65}^{64}$ O Nordeste, 11/3/1961, p. 3.

${ }^{65}$ Idem.

${ }^{66}$ O Nordeste, 20/5/1961, p. 3.

${ }^{67}$ Segundo Souza, a grande imprensa cearense (O Nordeste, O Povo, o Correio do Ceará e o Gazeta de Notícias), no decorrer dos anos de 1963 e 64, tratou o êxodo rural como resultado imediato da seca, negligenciando, assim, questões como a concentração fundiária e a identidade camponesa desses indivíduos. Além disso, esses periódicos apontavam o êxodo como algo natural ao cearense pobre que, como única saída, partia com seu espírito "desbravador" para construir pelo Brasil a fora.

${ }^{68}$ A ideia de harmonização do campo continuou presente nas proposições do periódico. A relação entre latifundiários e trabalhadores rurais era apresentada como harmônica, delegando ao latifundiário as características de solidário e altruísta. Cf. O Nordeste, 22/8/1961, p.4.

${ }^{69}$ Essa comparação tem como referência os textos "Quatro séculos de latifúndio (1963)" e "As três frentes da luta de classes no campo brasileiro (1960)", de Alberto Passos Guimarães, e "Problemas agrário-camponeses do Brasil (1968)", de Moisés Vinhas.

${ }^{70}$ O Nordeste, 7/3/1961, p.1.

${ }^{71}$ O Nordeste, $30 / 1 / 1962$, p.3.

${ }^{72}$ O Nordeste, $18 / 1 / 1962$, p.3.

${ }^{73}$ O Nordeste, 31/1/1962, p. 2.

${ }^{74}$ A partir do dia 11 de fevereiro, o jornal passou a publicar um suplemento especial aos domingos. A publicação desse suplemento fez parte de um plano de orientação ideológica acessível a toda categoria de pessoas sobre os mais palpitantes problemas nacionais, como o próprio periódico destacou na primeira página da edição de 6/2/1962. Nesse suplemento encontramos a coluna "Nordeste cooperativista", que circulou de 11 de fevereiro a 9 de setembro de 1962, com o objetivo de orientar sobre os princípios fundamentais da doutrina cooperativista.

${ }^{75}$ RICCI, op. cit., p. 51. 


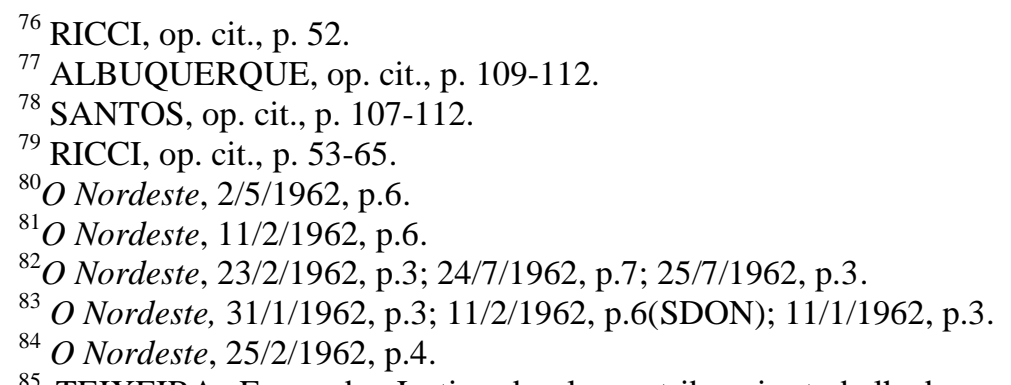

${ }^{85}$ TEIXEIRA, Fernando. Justiça de classe: tribunais, trabalhadores rurais e memória. Mundos do Trabalho, Florianópolis, v. 4, n. 8, 2012, p. 144.

${ }^{86}$ O Nordeste, 26/11/1963, p.2.

${ }^{87}$ MEDEIROS, Leonilde. Movimentos Sociais no Campo, Lutas por Direitos e Reforma Agrária na Segunda Metade do Século XX., p.122.

${ }^{88}$ Iguatu é um município brasileiro do estado do Ceará, que na década de 1960 foi importante centro produtor de algodão. Em 1963, os trabalhadores rurais da região passaram a ocupar as páginas do Terra Livre - periódico ligado ao PCB -, que noticiava as ações da Associação dos Trabalhadores Agrícolas de Iguatu, fundada em fins de 1962, e do Sindicato dos Produtores Autônomos de Iguatu. Cf. TERRA LIVRE, fevereiro de 1963, p.2; maio de 1963, p.7; abril de 1963, p.4; maio de 1963, p.6; junho de 1963, p.3.

89 "O Nordeste agrícola" era publicado no SDON.

${ }^{90}$ O Nordeste, $8 / 7 / 1962$, p.7.

${ }^{91}$ O Nordeste, 29/7/1962, p.7.

${ }^{92}$ O Nordeste, 16/3/1962, p.5; 8/7/1962, p.6.

${ }^{93}$ O Nordeste, 21/8/1962, p.3; 25/10/1963, p.4; 28/10/1963, p.4.

${ }^{94}$ Por exemplo, nos dias 2 e 11 de maio de 1962, páginas 6 e 8, foram publicados os seguintes editais de convocação: "Pelo presente edital, em cumprimento do Decreto Lei n. 7038 de 10 de novembro de 1944, do Ministério do Trabalho, e, tendo em vista a futura portaria ministerial sobre a sindicalização rural, ficam convocados todos os trabalhadores rurais da periferia de Fortaleza, a compareceram à Assembléia Geral, que se realizará, no dia 13 de maio próximo, às 19hs(sic.), na sede da Federação dos Círculos Operários do Ceará, sita à praça Cristo Rei s/n., nesta capital, onde se debaterá e se estudará a fundação da Associação Profissional dos Trabalhadores de Fortaleza"; "De ordem do Sr. Presidente, convoco os trabalhadores rurais do município de Fortaleza, para se reunirem em Assembléia Geral, no dia 27 do corrente, às 15 horas, e às 16 horas em segunda convocação, na sede do círculo operário de Messejana, em Fortaleza, a fim de deliberarem sobre: a) reconhecimento do sindicato b) leitura e aprovação dos Estatutos c) eleição provisória de administração para efeito e promover o referido reconhecimento junto ao ministério do trabalho. Fortaleza, 9 de maio de $1962-$ Paulo Ferreira da Costa - Secretário da Comissão Organizadora".

${ }^{95}$ DEL ROIO, Marcos. "A Teoria da Revolução Brasileira: tentativa de particularização de uma Revolução Burguesa em Processo". In:__ e MORAES, João Q. (orgs.). História do Marxismo no Brasil: visões do Brasil. v. 4. Campinas: Unicamp, 2014, p.81.

${ }^{96}$ O Nordeste, 12/1/1962, p.4.

${ }^{97}$ O Nordeste, 17/1/1962, p.4.

${ }^{98}$ O Nordeste, 20/5/1962, p. 1.

${ }^{99}$ O Nordeste, 16/1/1962, p.6.

${ }^{100}$ O Nordeste, 12/4/1962, p.3.

${ }^{101}$ O Nordeste, 8/6/1961, p.3.

102 O Nordeste, 29/7/1962, p.2 (SDON).

${ }^{103}$ O Nordeste, 4/5/1962, p.1.

${ }^{104}$ O Nordeste, 11/2/1962, p.3.

${ }^{105}$ O Nordeste, 4/5/1962, p.1.

${ }^{106}$ O Nordeste, 29/7/1962, p.2.

107 O Nordeste, 11/2/1962, p.3.

${ }^{108}$ O Nordeste, 8/2/1962, p.3.

${ }^{109}$ SOUZA, op. cit., p. 18.

\section{Referências bibliográficas}


ALBUQUERQUE, Ronald de Figueiredo. Igreja, Sindicato e organização dos trabalhadores. Dissertação de mestrado, Sociologia do Desenvolvimento, Centro de Humanidades, UFC, 1991.

ALVES, Márcio Moreira. A Igreja e a Política no Brasil. São Paulo: Editora Brasiliense, 1979.

AZEVÊDO, Fernando Antônio. As Ligas Camponesas. Rio de Janeiro: Paz e Terra, 1982.

CARVALHO, Abdias Vilar de. A Igreja católica e a questão agrária. In: PAIVA, Vanilda. Igreja e questão agrária. São Paulo: Loyola, 1985, p. 68-109.

CRUZ, Heloísa de Faria \& PEIXOTO, Maria da Cunha. Na oficina do historiador: conversas sobre história e imprensa. Projeto História. São Paulo, v. 35, 2007, p. 253-270.

DELGADO, Jaime Ornelas. Volver al desarrollo. Problemas del Desarrollo, Cidade do México, v. 43, n. 168, jan./mar. 2012, p. 7-35.

DEL ROIO, Marcos. A Teoria da Revolução Brasileira: tentativa de particularização de uma Revolução Burguesa em Processo. In: __ e MORAES, João Q. (Orgs.) História do Marxismo no Brasil: visões do Brasil. Campinas: Unicamp, 2014, 4 v., p. 73-134.

ECKERT, Cordula. O Master e as ocupações de terra no Rio Grande do Sul In: MEDEIROS, Leonilde Servolo; PAULILO, Maria Ignez; FERNANDES, Bernardo Mançano (Orgs.). Lutas camponesas contemporâneas: condições, dilemas e conquistas. São Paulo: Editora UNESP; Brasília, DF: Núcleo de Estudos Agrários e Desenvolvimento Rural, 2009, 1 v., p. 71-93.

FÁVERO, Osmar. Uma pedagogia da participação popular: análise da prática pedagógica do MEB - Movimento de Educação de Base, 1961-1966. Campinas: Autores Associados, 2006.

GRYNSZPAN, Mário. Mobilização camponesa e competição política no Estado do Rio de Janeiro (1950-1964). Dissertação de mestrado, Antropologia Social, Museu Nacional, UFRJ 1987.

KADT, Emanuel. Católicos Radicais no Brasil. Brasília, DF: UNESCO/MEC, 2007.

MAINWARING, Scott. Igreja e Política: anotações teóricas. Síntese, n. 27, jan./abr. 1983, p. 35-56.

MARTINS, José de Souza. Os camponeses e a política no Brasil: as lutas sociais no campo e seu lugar no processo político. 2. ed. Petrópolis: Vozes, 1983.

MBAYA, Etienne-Richard. Gênese, evolução e universalidade dos direitos humanos frente à diversidade de culturas. Estudos Avançados. v. 11, n. 30, 1997, p. 19-41.

MEDEIROS, Leonilde Servolo de. A questão da reforma agrária no Brasil. Dissertação de mestrado, Ciência Política, FFLCH, USP, 1983.

Lavradores, trabalhadores agrícolas, camponeses: os comunistas e a constituição de classes no campo. Tese de doutorado, Ciências Sociais, IFCH, Unicamp, 1995.

Movimentos Sociais no Campo, Lutas por Direitos e Reforma Agrária na Segunda Metade do Século XX. In: CARTER, Miguel (Org.). Combatendo a Desigualdade Social: o MST e a Reforma Agrária no Brasil. Tradução de Cristina Yamagami. São Paulo: Editora UNESP, 2010, p. 113-136.

MENDONÇA, Sônia Regina. Estado, Educação Rural e Influência Norte-Americana: 19301961. Niterói: Editora da UFF, 2010.

MOREIRA, Vânia Losada. Nacionalismos e reforma agrária nos anos 50. Revista Brasileira de História, São Paulo, v. 18, n. 35, p. 329-360, 1998.

PAGE, Joseph A. A revolução que nunca houve: o Nordeste do Brasil (1955-64). Rio de Janeiro: Record, 1972.

PAIVA, Marlúcia Menezes (Org.). Escolas radiofônicas de Natal: uma história construída por muitos (1958-1966). Brasília: Liber Livro, 2009.

RICCI, Rudá. Terra de Ninguém: representação sindical rural no Brasil. Campinas: Editora da Unicamp, 1999. 
RODRIGUES, Fabiana de Cássia. O papel da questão agrária no desenvolvimento do capitalismo nacional, entre 1950 e 1964, em Caio Prado Jr., Celso Furtado, Ignácio Rangel e autores pecebistas. Dissertação de mestrado, Economia, Instituto de Economia, UNICAMP, 2005.

SANTOS, Jovelina Silva. Círculos Operários no Ceará: "instruindo, educando, orientando e moralizando" (1915-63). Dissertação de mestrado, História Social, Centro de Humanidades, UFC, 2004.

SILVA, Fernando Teixeira. Justiça de classe: tribunais, trabalhadores rurais e memória. Mundos do Trabalho, Florianópolis, v. 4, n. 8, 2012, p. 124-160.

SINGER, Paul. Interpretação do Brasil: uma experiência histórica de desenvolvimento. In: FAUSTO, Boris (dir.) História Geral da Civilização Brasileira: o Brasil Republicano. Economia e Cultura. São Paulo: DIFEL, 1984, 4 v., p. 209-245

SOUZA, Enilce Lima Cavalcante. Campo e palavras: dimensões da questão agrária no Ceará, 1954-64. Dissertação de mestrado, História Social, Centro de Humanidades, UFC, 2005.

TAPIA, Jorge. Capitalismo e questão agrária: um estudo sobre as alternativas para a Reforma Agrária no Brasil (1946-64). Tese de mestrado, Ciência Política, IFCH, Unicamp, 1986.

WELCH, Clifford Andrew. A Semente foi plantada: as raízes paulistas do movimento sindical camponês no Brasil, 1924-64. São Paulo: Expressão Popular, 2010.

\section{Fontes}

O NORDESTE. Edições de janeiro de 1961 a novembro de 1963.

TERRA LIVRE. Edições de fevereiro a junho de 1963. 